\title{
1924 年の加曾利貝塚調査
}

\author{
西田泰 民 ${ }^{1 *}$ \\ 1 新潟県立歴史博物館
}

\begin{abstract}
要 約
1924 年に小金井良精によって行われた千葉市加觰利貝塚に打ける発掘調査については同年八幡一郎が 簡略な報告を人類誌上で行ったのみであった。その調査経緯と発掘後の整理について小金井の調査野帳と 日記から再構成し，現存する東京大学総合研究博物館の遺物・写真資料と対比検討した。また，記録から 現地に協力者がいて，宿舎を提供していたことや，地主との交渉のあり方，発掘費用など，これまで全く 知られていなかった調査の全体像を知ることが出来た。明治・大正期は東京人類学会の遠足会に見られる よらな無計画な発掘が少なくなかったが，次第に分層発掘や出土地点を記録するために調査区を設定した 上で発掘を行ら方式が定着した。そのような過程を知る上でも重要な記録と考兄られる。
\end{abstract}

キーワード：加筸利貝塚，発掘調査，大正，小金井良精

\section{The excavation at the Kasori shellmound in 1924}

\author{
Yastami Nishida ${ }^{1 *}$ \\ ${ }^{1}$ Niigata Prefectural Museum of History
}

\begin{abstract}
In 1924, Dr. Yoshikiyo Koganei, the first Japanese physical anthropologist, conducted an excavation at the Kasori shellmound. A brief site report was made by Ichiro Yawata, but its final report had not been published since then. Recently the author discovered Koganei's fieldnote in which the details of the excavation is recorded. The process of the excavation from its planning to the post-excavation research is now revealed. The record tells the details as to the negotiations with the land owners and the expenses. In the early stage, the excavations in Japan was not systematic and more like treasure hunting. In the 1920's gradually the more organized excavation methods began to be applied. This record is important in this regard as well.
\end{abstract}

\section{はじめに}

千葉市若葉区に所在する加曽利貝塚は国内最大級の貝 塚であり，明治期から幾多の発掘調査が行われてきてお
り，現在特別史跡の指定に向けて，これまでの調査資料 の再整理が行われている。筆者は数年来新潟県長岡市立 中央図書館文書資料室が保管する小金井良精資料等の整 理に携わる中で，この貝塚で1924（大正 13）年に行わ

*新潟県立歴史博物館

干940-2035 長岡市関原町 1-2247

E-mail: nishida.yasutami@pref.niigata.lg.jp

(C)2014 The Anthropological Society of Nippon 
れた調査が記録された野帳が別途保存されていたことを 見出した。この調査については人類学雑誌 39 巻に拀い て八幡一郎による簡単な報告がなされたのみである（八 幡，1924）。調査から90 年を経て，小金井の野帳及び日 記の記述からその経緯をここに紹介する。

\section{発掘に到る経緯}

いつ頃から小金井が加曽利貝塚の発掘調査を具体的に 計画したのかは日記からは明らかにできていない。八幡 （1924）には, 明治 40 年の人類学会遠足会の後の坪井正 五郎らの発掘で出土した人骨が提供されて以来の計画で あったという。なお, 加曾利貝塚で開催された人類学会 の遠足会のらち, 小金井は明治 40 年には不参加, 大正 4 年には参加している。

直接のきっかけになったことがうかがわれるのは調査 の 2 年前の大正 11 年 8 月 17 日の日記にある次の記述で ある。な拈，原文はカタカナが使用されているが，ひら がなに改めたほか，仮名遣いはそのままとした。また一 部旧字を新字に改めた。

「大山柏，松村両氏来室 長談六時を過ぐ Urbewohner 論 を貸したり」

次いで，9月 1 日には「小川町にて千葉の地図一枚買 ひて」とあり，翌日の 9 月 2 日，「昼頃大山，松村二氏 来室, 大山氏去三十日加曽利, 貝塚の二貝塚を探検した るよし, 両所共発掘に值す, 鬼に角かそりとして尚ほ来 五日同所実測を約す」とある。加曽利に加兄て貝塚と併 記されているのは, 字貝塚にある荒屋敷貝塚のことであ ろら。こうして 9 月 5 日, 予備調査が行われた。

「約束の通り加曽利行, 八時両国駅発車, 千葉より歩く, 大山，松村二氏の外大山氏従者五名，炎天熱し

十一時二軒屋に達し, 小唕,

貝塚を一週し一時戻りて弁当

午後大山氏測量，松村自分は試掘，家主と談合，

十月下旬発掘作業を始むることを約す」

その後, 9 月 8 日「午刻松村氏来室大山氏貝塚測量図 持ち来る」，9月 9 日「午食後直に人類教室へ行きて鳥 居氏に加曽利貝塚発掘のことを謀る, 賛同することを快 諾したり」と順調に準備が進んだかに見える。

しかしこの調査は, 9 月末に松村遼から情報がもたら され，急遽実施が決定された伊川津・保美貝塚の調査に よって中止された。

10 月 26 日「時に大山, 松村二氏来室, 発掘談, 其結 果加曽利を延期して渥美半島の方を継続するを適当と 決す」
11 月 1 日「加兽利貝塚発掘延期することを海保定吉へ 通知寸」

海保の名前はここで始めて登場するが，この 2 年後小 金井が海保宅を宿舎とする。9 月5 日の予備調査の際, 家主とあるのも同一人物と考光られる。

大正 11 年の調査は中止となったが，小金井は翌年に 調査を行らつもりであったらしい。大正 12 年 5 月 5 日 には加曽利を再び一人で訪れている。

「自分は加曽利行, 昨秋発掘の計画なりしも延期し拈き たるが様子如何にと思ひてなり

十一時松林中古墳の影飞て弁当を使ら 静寂甚快

一時間余榎ひて 字古山, 海保方に到る, 先般製石灰の ため貝殼を取りたる際出土せる遺物数個を見る完全土器 （図）形のもの，大形土瓶，たたき石数個，濃赤塗り土 器片, 石血, 最も珍しきは小動物下顎体の一歯付きたる 有孔の濃赤塗り切片。

貝塚巡検中上羽氏に会す, 四時過帰途に付く,

駅にて三輪徳寛氏に逢ふ，車中歓談」

古墳とあるのは現在も加曾利貝塚公園内にある新山 1 号墳であろう。古山は貝塚のすぐ南に隣接する字名 である。上羽氏とはいわゆる遺物採集者であった上羽 貞幸氏である。帰りに遭遇した三輪氏は明治 21 年東大 大学院を修了後, 外科助手を務め, 明治 22 年からは後 の千葉医科大学々なる第一高等中学校医学部教諭に任命 された。大正 12 年当時は千葉医科大学の学長となって いた。

この訪問後, 小金井は同年秋に加兽利貝塚の発掘調査 を行ら計画を立てたよらである。

5 月 7 日「人類教室に松村氏に加曽利発掘は九月とする ことを通す」

しかし，9月 1 日の関東大震災により，発掘は断念せ ざるを得ない状況となる。

10 月 20 日「加曽利へ貝塚発掘延期することを申送る」

明けて大正 13 年, 延期していた調査を春に行らこと が突如決定する。

「三月十六日 日 晴

加兽利貝塚発掘打ち合せに出向, 千葉より兼坂まで人車 （七○銭）総て好都合

来二十四日 (月曜) より着手のこととす，天気特に春め きて快, 七時前帰宅」

兼坂は現在の 51 号線桜木町の交差点付近の字名で, 貝塚まで約 $1 \mathrm{~km}$ である。大正 13 年の日記に加兽利のこ 
とが書かれているのは, この日付が最初であり, この打 ち合わせに誰が参加したのか，それまでにどのよらな準 備があったのかは全くわからない。扣りしも，松村の博 士論文審査にともない，鳥居龍蔵助教授の辞職問題が新 聞沙汰にまでなった時期であり，日記には加曽利調査の 準備については書く余裕がなかった模様である。とにか く, この一週間後, 最初の計画から 2 年を経て, 加曽利 貝塚発掘が実行されることとなった。な抒予備調査に参 加した大山柏はこの時, ベルリンにあった。

\section{加曾利貝塚発掘}

以降，野帳の記述を基本に，日記の記述によって補い ながら調査状況の再構成を試みる。

\section{三月二十四日 月 晴}

午後一時頃着手，大山氏製図 B 地点，これは同氏及昨 年十一月上羽氏試掘の地,

今日は主として掘り返へしをさらひたり且つ表土を除く

この日の参加者については日記の方に記載されている。 「荷物は先に送り自分きみ八時出かける, 三二駅まで行 く，松村氏等あり，Junker 氏来る，

八時三五分に間に合うに付これにて出発, 車中 J. 氏雑談, 松村氏, 甲野, 八幡, 宮坂, 山内総て五名は次の列車に て着葉,

千葉にて荷車に困る

これを捜しきみ子同断，幸に海保主人の荷車を引かして 寝具貸り入れるため来葉せしに会ら，これに大包を托し 他の手荷物は人車に各分かち J 氏と三人発す

諸氏は歩きて来る 兼坂にて車を下り, 手荷物を一農家 に托し十一時海保方に着寸, 携たる弁当を食し一時半 現場に到り発掘を始む,

森田秀一氏今朝早く来り居る

此日は $\mathrm{B}$ 地点既掘をさらひ且つ付近表土を取り除きて 五時仕舞了,

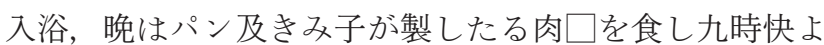
く臥床に入る

Junker 氏再来を約して夕方帰京，森田氏同行」

当時は総武線は両国（橋）駅からであったので，この 場合の駅も両国のことと思わ机る。三二は小金井の次男 である。乗車時間は千葉までほぼ 1 時間であった。 Junker 氏とはエミール・ユンカー（ユンケル）のことで, 当時は独逸学協会学校 (後の獨協大学) にあり, OAG

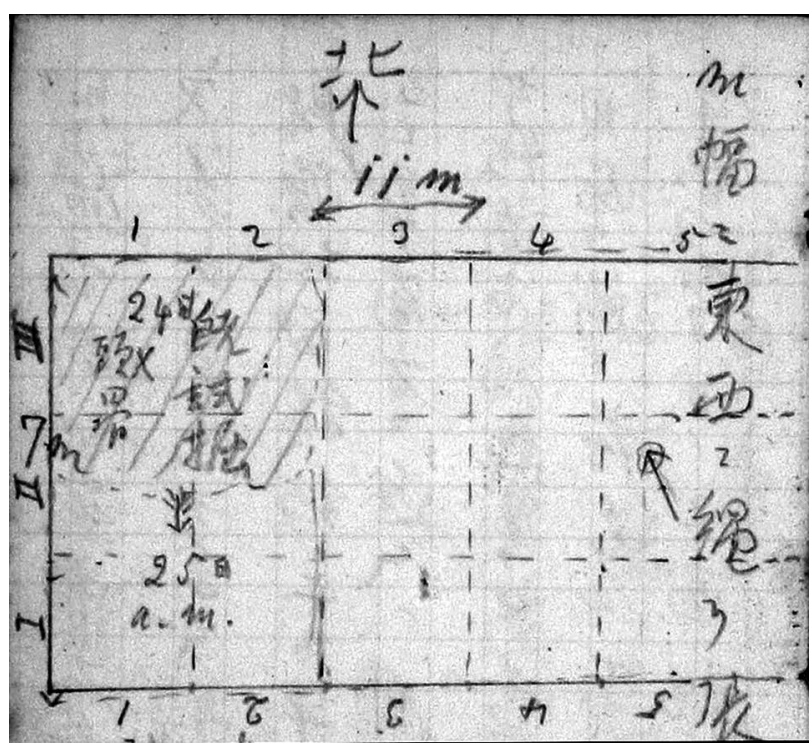

図 1 野帳より

ドイッ東洋文化研究協会で，小金井はしばしば会い，独 文のチェックも依頼していたよらである。森田秀一はこ の時解剖助手で，のちに千葉医大教授となる。

三月二十五日 火 量

午前九時始む 先つ試掘地を含久て南北七 $\mathrm{m}$ 幅に東西 に縄を張り東に進むこととす

昨日既試掘地に於て計測したるに表土一尺七寸 貝層三 尺 黄褐色黒土一尺余以下地盤赤地，即ち表面より六尺 にて地盤となる

貝層下黄黒土中厚き土器片多数出

又多少貝片を含む

既掘地面積約 $3 \mathrm{~m}$ 平方

これより南方に進む貝層二尺，褐色土二尺余

午後南方褐色層中土器, 獣骨あり

貝層漸々薄くなる七, 八寸

午後四時半 II の 2 区褐色層六寸の深さより

人大腿骨右五寸の長さ片出る

其直に左に大甕あり周囲に灰夥しくあり

下は赤地に層に達す（写真）

加曽利貝塚 B 地点の平面図が記されている。八幡 （1924）には $2 \mathrm{~m}$ 四方のグリッドを組んで，20区を設け たと記されているので，やや計算が合わない。また，写 真撮影をしたことが記されているが，写真についてはま とめて後に述べる。

喜美子夫人が同行しているせいか，食事は小金井好み 
であったようだ。「昼はサンドウィッチを製して供す， 晚は鷄の馳走」

三月二十六日 水 雨

森田氏雨中来，小池箕内二氏送迎会の件

三月二十七日 木 晴

前九時開始 I の 2 区貝層を払ふ，其底部より人歯（u.P） 一本出る, 其直上に獣骨及土器片数個ありたり

午後 III の 2 褐色層より骨の大なるもの現はれ人腸骨か と思ひたるも全く獣骨なりき

三時驟雨農小屋に避けて皆々休㰾三時を食す, 作業休止 Junker，五島理学部長来，三，坊来

この日は小金井三二が小金井の孫柿内賢信（10 歳） を連れてくる。小金井はそれぞれ三，坊と記している。 雨宿りをした時の三時のおやつは「きみが製せしドオ ナッ」であった。

三月二十八日 金 晴

九時開始， $\mathrm{B}$ 地の外北東の $\mathrm{E}$ 地点を新に設けて着手す傾 斜し東方に面す

東西に巾一 $\mathrm{m}$ に上より下に向かいて溝を試掘す

紋様 B と違ら浮紋厚手式なり

下方に漸々貝層薄くなる, 貝層下暗褐色土, 以下漸々赤 くなる (地盤)

$\mathrm{B}$ 午後三時前人 1.Temporale 褐色から出る又人 Occipitale 一個坊発見

この後頭骨は上羽氏頭骨の破片と合致す

$\mathrm{E}$ 地東西 $2 \mathrm{~m}$ 南北 $10 \mathrm{~m}$ 。表黒土五寸位, 貝層一尺位, カシャゴ多し，褐色土一尺位にて赤土となる

松村氏完全鹿角器発見

宮坂，山内二氏 E 飞従事

八幡, 甲野氏 B に従事

寒風，矢津氏息を携て来観，

晚家主に D地点発掘の件を談す, 持主千葉なるを以て明 朝松村氏同道にて行き承諾を求めること, B 地は明日 $7 \mathrm{~m}$ 東方， $\mathrm{E}$ 地は $2 \mathrm{~m} 10 \mathrm{~m}$ とて終結し予算等のことを談合

後に加曽利 $\mathrm{B}$ 式, 加曽利 $\mathrm{E}$ 式と山内清男が命名する ことになる地点による土器の違いを小金井も書き残して いる。3 月といっても一時的に気温が下がったらしい。 日記には「寒強, 霜白し」とあり, 銚子気象台のデータ では28日の最低気温 $0.5^{\circ} \mathrm{C}$, 翌 29 日の最低気温は $-0.7^{\circ} \mathrm{C}$ とっている。またこの日「坊もまんがを取て 貝塚を掘り」「J. 氏も自らまんがを取る」と記述があり, 当時は熊手形の鍬をつかって発掘をしていた。この日， 訪れた矢津氏については，八幡（1924）では発掘期間中 の見学者として谷津博士が挙げられていることから，東 京大学動物学教室教授の谷津直秀のことと考光られる。

三月二十九日 土 晴

朝霜柱二寸余, 珍らしき寒さなり, き久坊と山林中散歩, 松村氏家主と千葉行，濱田吳服持山林発を交渉す，午刻 前に帰りて三坪の承諾を得たりと, 昼食後一時半出て両 人坊を連孔て帰京

$\mathrm{D}$ 地点の発掘の許可を得るため松村が家主と共に地主 である千葉の濱田呉服店に赴く。濱田吳服店は古川 （1911）によると当時千葉町吾妻町 1 丁目（現千葉市中 央区中央）にあった「千葉町随一の呉服店」であり, 店 主は「千葉町屈指の資産家」であったという。

3 月 30 日, 小金井は横浜へ娘婿の柿内三郎（賢信の父） の帰国出迎えのため, 横浜へ行く。そのため野帳にこの 日の記述はない。八幡 (1924) では発掘の休止は雨の 26日のみと書かれていることから，この日も調査は継続 されていたよらである。また, 八幡が挙げた遺跡見学者 のらち，入澤医学部長の名が小金井の記録には見当たら ないことから，この日に入澤達吉が来訪したと見られる。

三月三十一日 月 晴

十一時五○古山着, 家婦人骨出たるを知らす

昼食, 現場に到る $\mathrm{E}$ は中止, $\mathrm{BD}$ より各一体つつ出たり, 自分はBのものにかかる

II の 5 貝層下褐色土中, この地点より東方貝層薄くなる 頭北北西, 水平, 伸なるべし, 上肢稍伸, 下肢伸なるべ し，これを取り揚げて仕舞ふ

人骨深位表面より $1,20 \mathrm{~m}$ (甲野氏測)

八幡氏帰京

$\mathrm{D}$ 今日着手, 東西一間半, 南北二間, 緩傾斜, 小丘の西 に面す

[整骨の際後記］下顎右半分と上顎の一部と土塊のまま 袋に入れ (下顎左半分は別にあり) 而して丁度下顎内を 充たす土塊中に角器（槍の注さき）ありて其尖は下方に 向って土塊にささり居たり

前夜，東京の自宅に泊まった小金井夫妻は朝出立し， 
昼前に加曽利に到着し, 人骨出土を知る。日記には「自 分は始めて仕事にありつきたり」とあり，八幡（1924） では「そして此時初めて博士は篦を握って静かに発掘に 掛られた。私達は片唾を吞んでその傍に佇み乍らこの大 きな事実に直面していた」と調査のクライマックスを記 している。B 地点の平面図にある矢印は出土地点と頭位 方向と考光られるが，そ机以外は状況が書き込ま机な かった。

四月一日 火 晴

千葉行，D 地点大に有望なるを以て尚ほ三坪追加発掘を 試んため先つ田口氏に相談,

橋本書記に謀り同道山林主濱田咫服店に到り番頭某と面 会陳情の末承諾を得たり

松村氏一部の荷造りをなす

午後 D 地 骨格を検す貝層中而も其上部に在る

胴部中断せる様なり 頭東 ? 即ち左脛骨は頭の西に離し て在る，其傍に腓骨もある，併し頭椎は頭の南に並ぶ而 て胴は中断す

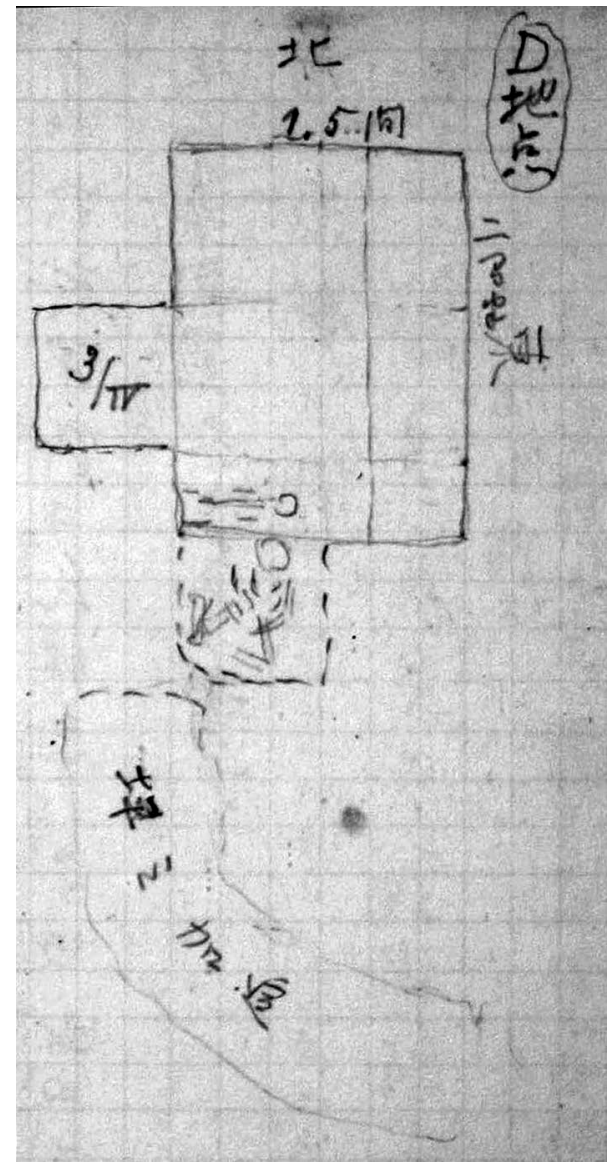

図 2 野帳より
これを取り揚げたらば更に第二の頭骨現はる又右の肩 胛，上膊も見ゆ

このままにして止める

追加三坪は

午後松村，甲野二氏帰京，宮坂山内二氏残る

三二来りて主家家屋を画く

D 地点でさらに追加発掘を行らため，小金井は千葉医 大に田口碩臣教授を訪ね，橋本書記を伴って，再び濱田 点服店に交渉に出向き，承諾を得る。その結果，「始め 今日帰京の予定なりしも人骨出たるを以て尚活事業を延 長す」ることとなった。「追加三坪は」の後は空白となっ て打り, 何を書こうとしたのかはわからない。八幡(1924) には丘陵の脚を細長く試掘したとあり, 図にも逆ノ字状 の発掘範囲が書き込まれている。

小金井三二の描いた絵は，小金井の日記によれば「記 念として宿に贈るもの」であった。

四月二日 水 曇雨

$\mathrm{D}$ 第二骨は貝層中部，表面より二尺黒表土一尺，貝層二 尺余

貝は，八マグリ，キシャゴ最多，マキガヒ，カキ

第二号骨。頭北，屈葬，下肢右股関節，膝関節屈，右方 飞到る，左股関節伸，膝屈，上肢右稍伸，手右慰部に在， 左稍伸。

午後取り揚げ終る頃雨降り出す，作業中止，時に三時を 過ぐ

時に八幡氏再来，三二朝より手つだう

宮坂氏帰京，帰郷すと，次に三二も雨中去る

明日は山内，八幡二氏となる

後記 D 地点第二号人骨整理の際胴，肢骨袋中より猪牙 器（腰飾）を発見す（頭は別袋に置きたれば決して頭附 属のものにあらず)

四月三日 木 小雨量

天気模様甚疑はし，八時半始屯

D 地を西方へ $2 \mathrm{~m}$ 幅に進む（前図を見よ）

但乙全く不結果

十時良一来る，発掘にたづさはる， B 地に転じ III の 5 を試む，午後はI の 5 掘り反へして 此度の発掘事業終

小金井の長男良一が最終日の発掘に参加する。家主か ら絵の返礼なのか日記に「ジネンジョを贈るといひてこ 
れを掘るのを見る」とある。

調査終了に伴い，荷造りが行われ，「三骨格を荷造り す石油箱一個に詰める」。石油箱は石油の一斗缶（約 $25 \times 25 \times 35 \mathrm{~cm})$ が 2 本入る木箱である。

\section{発掘後}

野帳の記述は以上であるが，日記には翌 4 日，荷造り を済ませ，家主や人夫に謝礼を払って帰ったことが書か れている。また，現在東京大学総合研究博物館に保管さ 孔ている骨製装身具に大正 13 年 4 月 4 日海保菊次郎寄 贈と記述があり，この時提供されたものらしい。

そして，その後の日記から関連する記述を抜き書きす ると，「四月十日 松村氏来り加曽利荷物を届け呉孔た り」

「四月十二日 加曽利荷物一個を開く」

「四月十四日 人類教室へ行き松村, 甲野，八幡氏に加 曽利の挨拶 加曽利骨格を取り出す」

「四月十五日 加曽利人骨洗ひ始屯

松村氏加曽利写真焼きたりとて十七枚持ち来る」

「四月十六日 終日骨洗，D 地骨二体終る，第二号骨胴 部の袋より腰飾一個発見す」

「四月十七日 人類諸氏に昨日発見の腰飾を示す且つ置 きて去る

カソリ別口鶴見人骨を洗ひて骨洗終る」

とあり，ここで，一連の作業は終了したようである。

その後，小金井宅で慰労会が催された。

「四月二十四日 午後人類教室, カソリ諸氏皆在り, 来 土曜一会を催すこと皆承諾」

「四月二十六日 加曽利発掘慰労の意味にて松村, 八幡, 山内，宮坂，甲野五氏を招く，貝塚談，十時散す」

発掘記録とは別に野帳の最後の方のページに費用のメ モがあり，内容から見て加曽利貝塚調査のための出費と 考光られる。

発掘地弁償として，坪あたり 50 銭，また伐採木につ いては一本あたり 50 銭ないし 2 円，計 42 円 50 銭とし ている。また運搬用の箱や縄など発掘用品として 7 円 78 銭，人夫賃延べ 39 人分， 78 円，人類学教室からの参 加者を含めた食費 34 円 50 銭，夜具料 21 円 60 銭，宿泊 料 11 円，荷馬車 11 円とあり，合計すると 206 円 38 銭で ある。鉄道料金などは各自自前といらことだったらしい。 当時大卒の初任給が 70 円から 80 円とされるので，現在 の感覚でいらと発掘費用は 50 万円程度にあたろらか。

\section{再訪}

1926 年，汎太平洋学術会議が日本で開催されたのに ともない，エクスカーションの1つとして加曽利貝塚の 見学・発掘が計画された。小金井の日記には 10 月 26 日 に松村，八幡と千葉に行き，県庁職員と地主代人と共に 現地下見を行い，D地点を掘ることとして縄張りをした と記載されている。また 11 月 6 日の見学当日は外国人 7 名を含む参加者が，県庁から手配された車で現場に向 かい, 発掘を行ったが珍品の出土はなく, 各自出土土器 を袋に入れて持ち帰ったという。

\section{東京大学総合研究博物館収蔵資料との対応}

この 1924 年の発掘による出土人骨 3 体は東京大学に抏 いてUMUT131048～131050 として, 整理保存され，Web 上のデータベースにて公開されている。しかしながら， 小金井が特記した 3 点の骨角器がぞれであるかは判然と しない。特に $\mathrm{B}$ 地点， $\mathrm{D}$ 地点の人骨に伴らそれぞれ 1 点 が気にかかるところである。現在，八幡資料として保管 されている骨角器が候補として考光られるが，付属する カードに記載された内容と形状が医淩符合するのはB地 点出土の骨角器であり, 現在の分類でい光ば骨鏃である。 一方， D 地点 2 号人骨洗浄中に見出された牙製腰飾りに ついては，特定出来る資料が見いだせなかった。

\section{写真と発掘地点}

小金井が松村から提供された写真が 17 枚としているの に対し, 人類学教室写真アルバムには松村の写真が 18 枚 ある。現在経じられている順に $1 \sim 18$ とする。 5 枚が遺 物写真（1，12，13，14，15）でそれ以外の 13 枚が調査 時の写真である。小金井の数光間違いでなければ，遺物 写真のいずれかが，後に撮影されたのかもしれない。人 骨出土状態の写真はない。

日誌に写真を撮ったことが記載されているのは 3 月 25 日の久である。縄文地の胴部の張った土器と灰が写っ ている写真 (5) が該当する。調査時の写真のうち 2 枚 (9, 16）が，村田六郎太（2013）に E 地点の写真として紹 介され，それぞれ宮坂・山内，八幡・甲野が写っている。 しかし，日誌及び八幡（1924）の記述では E 地点は宮坂, 山内の担当であり，八幡，甲野の担当は B 地点であった。 また甲野の右に写っている杭に III と番号が振ってある ことからも，グリッドが設定されたのが $\mathrm{B}$ 地点のみで あったらしいので，八幡・甲野の写っている写真 (16) はB 地点であろう。このグリッド杭 III が写っているも 
ら一枚の写真（17）があり, 西から B 地点を撮った写 真であるように思わ机る。算用数字のグリッド杭 2,3 が写るトレンチ断面写真（8）は，B 地点の北断面であ ろら。宮坂が独りで写る写真（10）は貝層が厚く B 地 点か $\mathrm{D}$ 地点の可能性がある。また, やや離れた位置か ら発掘状況を撮った写真（18）には帽子をかぶり髦のあ る人物 2 名と子供が写っている。小金井とユンカー, そ

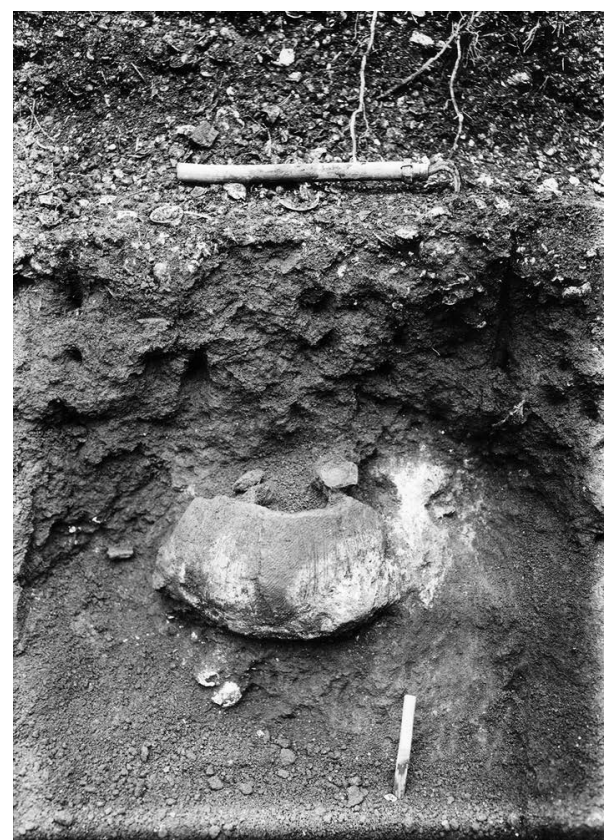

図 3 土器出土状沉 (写真 5)

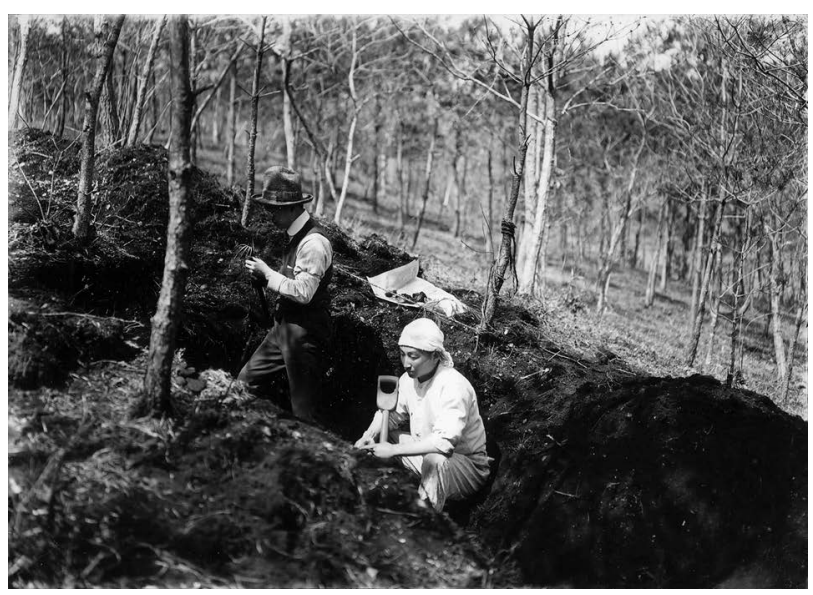

図 4 E 地点 宮坂光次と山内清男（写真 9)

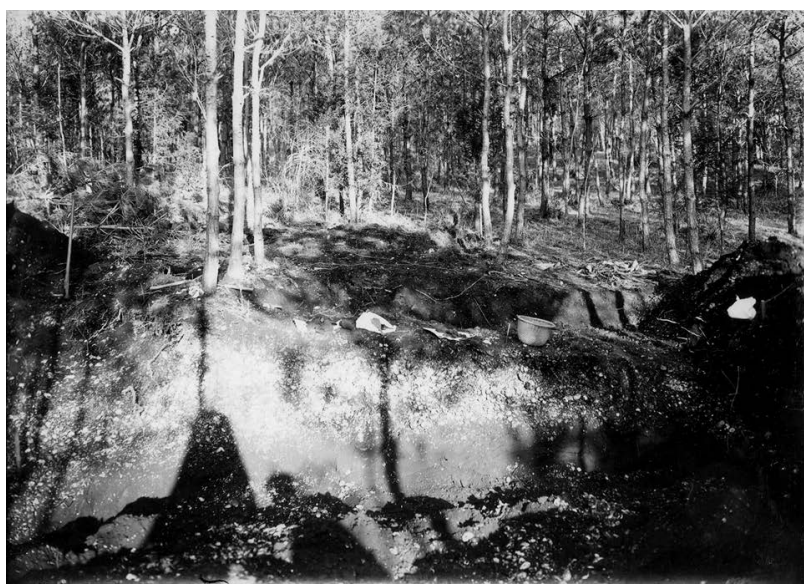

図 5 D 地点 西から（写真 2)

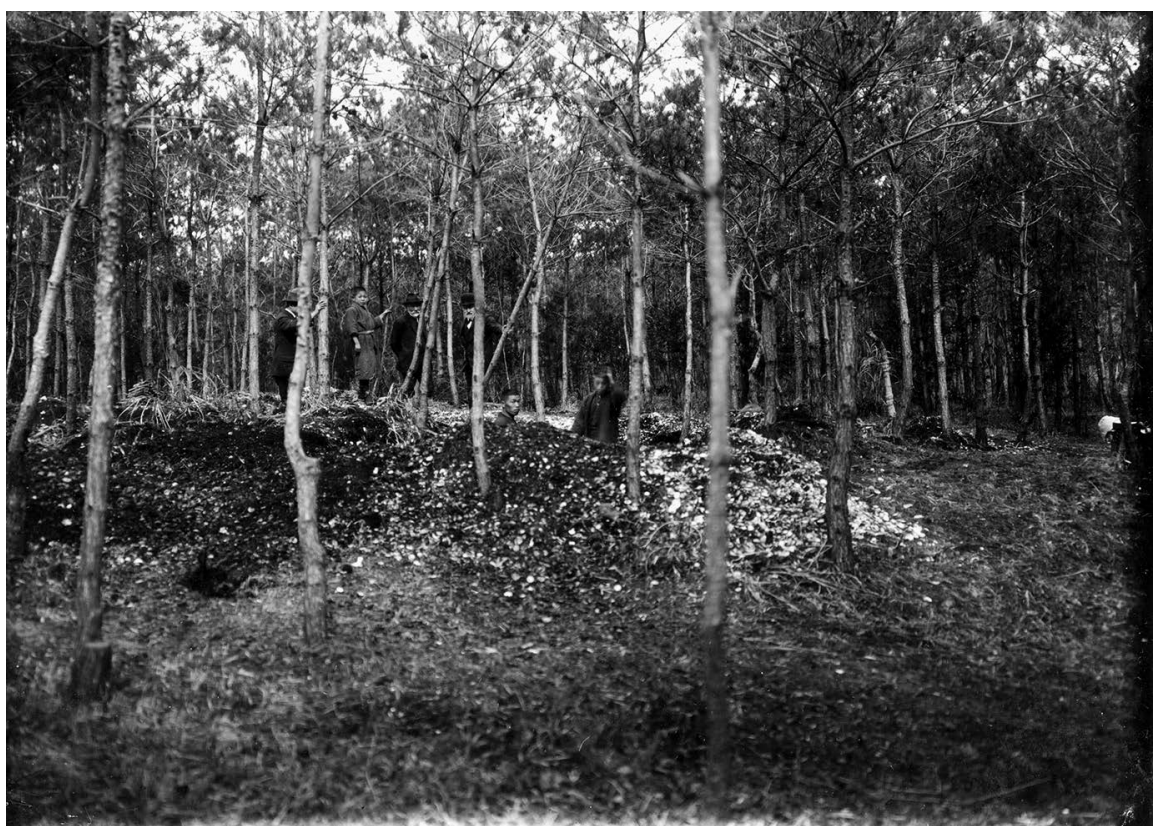

図 6 B 地点か，小金井とユンカー（写真 18） 


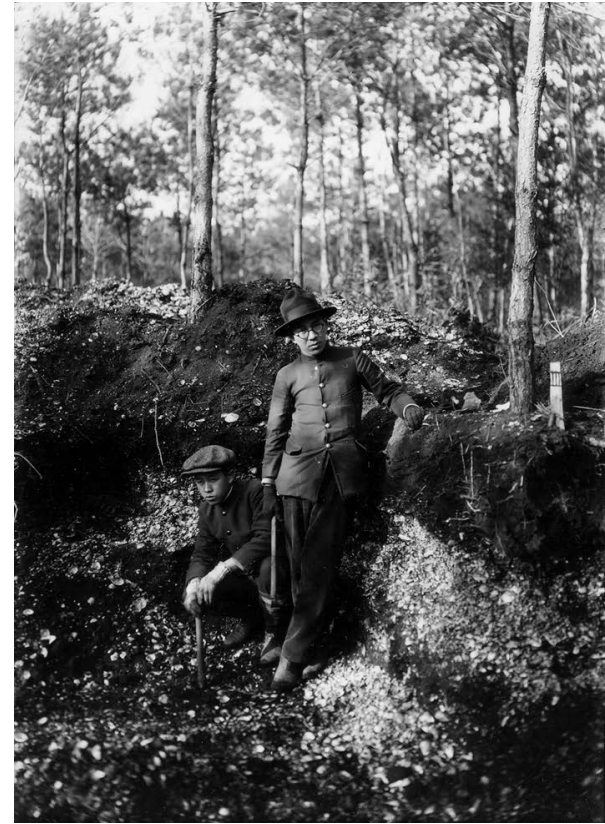

図 7 B 地点 八幡一郎と甲野勇 (写真 16)

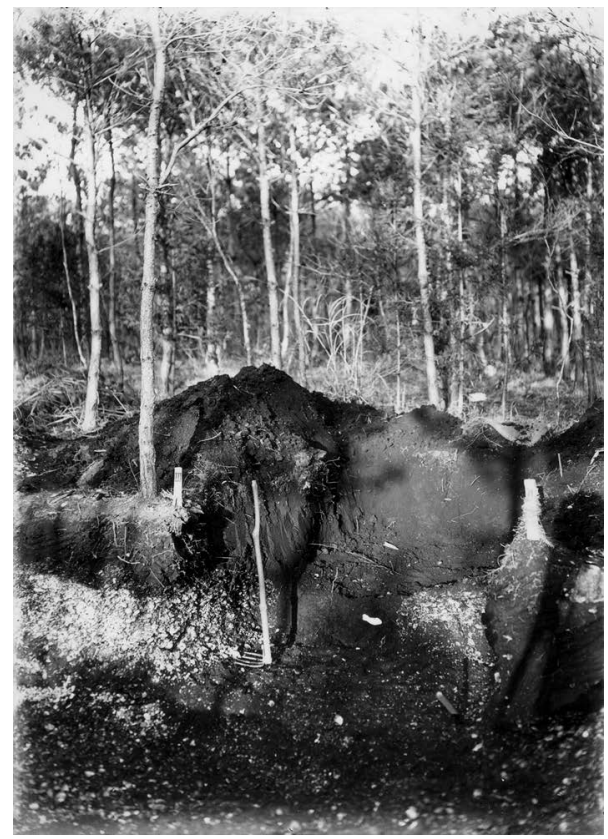

図 8 B 地点 西から（写真 17）

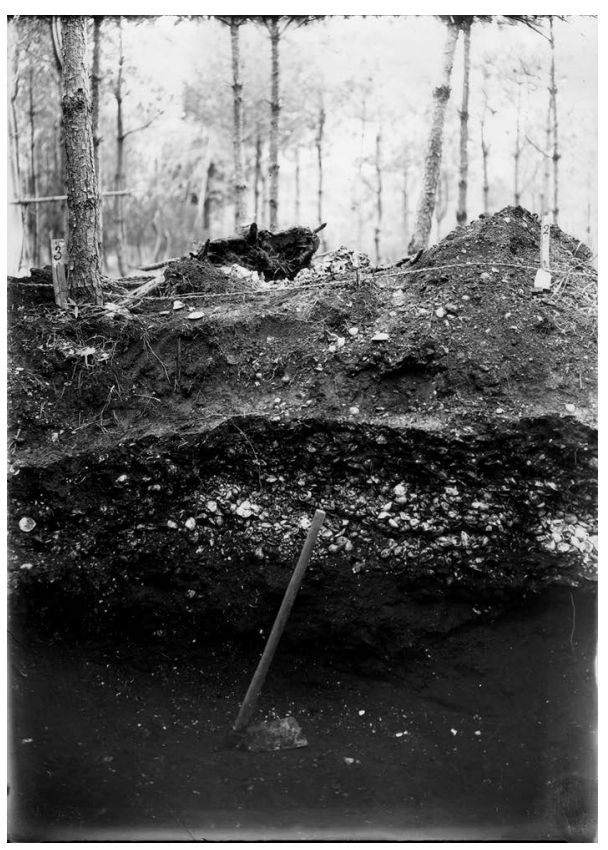

図 9 B 地点 北壁 (写真 8)

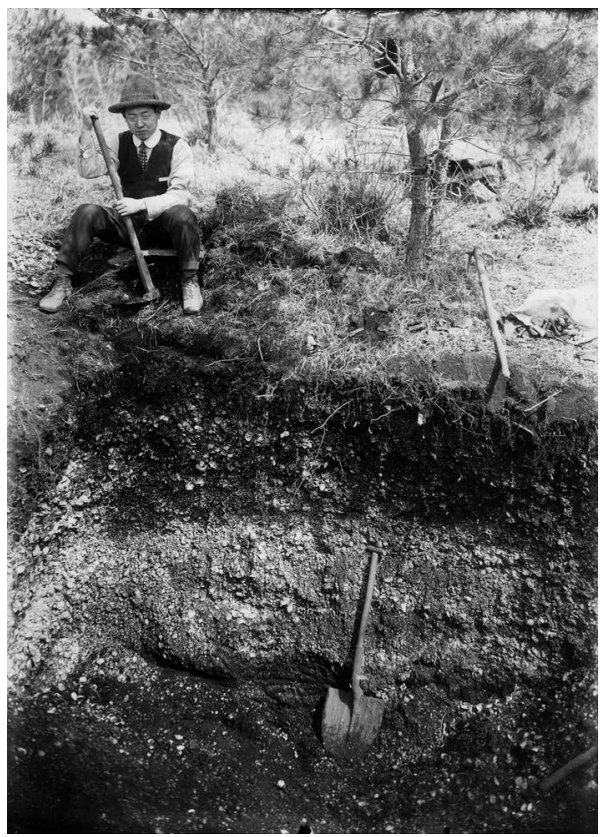

図 10 B あるいは D 地点 宮坂光次 (写真 10)
して杮内賢信であると考光られ，3月 27 日の B 地点と いらことになろらか。西日を背にして撮ったと思われる トレンチの写真（2）は南北に長いトレンチであること から D 地点であろら。その他，6，7，11 は地形から E 地点の写真と見られるが，3，4の2 枚は地点特定の手 がかりに乏しい。
具体的な発掘地点の位置は大山史前学研究所 (1937) にわずかに言及されて扣りそれを参考にするしかない。 掲載された略測図は精度があまり高くないため, 現在の 地形図と対応させることは難しい。B 地点は大まかに南 貝塚の南東部，D地点は同じく南貝塚の西斜面， E 地点 は北貝塚の東斜面とする程度である。 


\section{終わりに}

以上，小金井の日記及び野帳から 1924年の加曽利貝塚 発掘調查について記した。出土地点の特定や人骨出土状 況など今後の研究にいかせるものがあれば, 幸いである。

また，この時期から発掘調査は東京人類学会が明治 37 年から度々行った遠足会のように任意の地点を単に 遺物を求めて掘る方式ではなく, 分層発掘や記録を念頭 に扮いた発掘区を設定した上での調查方法へと変化して いく。その過程を知る上でも貴重な資料と考兄られる。

\section{謝辞}

この調査に関する野帳と日記の閲覧と公表について御許 可をいただいた岡本洋子氏，及び星マリナ氏に御礼申し上 げます。また，東京大学総合研究博物館の諏訪元教授，稲 葉佳代子氏，佐宗亜衣子氏には資料の所在確認について多 大な御協力をいただいたほか，翻刻にあたり馬場悠男先生 からも御教示をいただいたことを記し，感謝申し上げます。

\section{引用文献}

古川國三郎編（1911）千葉街案内. 多田屋書店, 千葉.

村田六郎太 (2013) 加曽利貝塚 東京湾東岸の大型環状貝 塚. 同成社，東京.

大山史前学研究所（1937）千葉県千葉郡都村加曽利貝塚調 査報告. 史前学雑誌，9-1: 1-68.

八幡一郎 (1924）千葉県加曾利貝塚の発掘. 人類学雑誌, 39: 209-212. 